\title{
Assessment of Microbiological Quality and Safety during the Processing of Traditional Beers made from Sorghum in the "Mandara" Mountains of the Far-North Region of Cameroon
}

\author{
James Ronald Bayoï, François-Xavier Etoa
}

\section{ABSTRACT}

\begin{abstract}
Indigenous beers are very popular and widely consumed by people from northern Cameroon because of its low cost. Despite their appeal, microbial quality of these beverages remains a serious call for concern. This work was aimed to investigate microbial changes and hazards of contamination during the processing of two special sorghum beers brewed in northern Cameroon. Producers were observed during the production and samples were collected at different stages for analysis of microbiological parameters such as total count, fungi, spore-forming bacteria, Coliforms and $E$. coli using referenced methods. Total count ranged from $13.5 \times 10^{3}$ to $195 \times 10^{3} \mathrm{CFU} / \mathrm{mL}$ and 0.16 $\times 10^{3}$ to $660 \times 10^{3} \mathrm{CFU} / \mathrm{mL}$; fungi from $0.26 \times 10^{3}$ to $22 \times 10^{3} \mathrm{CFU} / \mathrm{mL}$ and $0.22 \times 10^{3}$ to $85 \times 10^{3} \mathrm{CFU} / \mathrm{mL} ; E$. coli from $0.69 \times 10^{2}$ to $13.6 \times 10^{2} \mathrm{CFU} / \mathrm{mL}$ and $0.65 \times 10^{2}$ to $3.8 \times 10^{2} \mathrm{CFU} / \mathrm{mL}$ during the production of the red "té" and white "mepdli" beers, respectively. Spore-forming bacteria and Coliforms (total and fecal) were detected in all the collected samples. Bacterial spores were also enumerated in red $\left(38 \times 10^{3} \mathrm{CFU} / \mathrm{g}\right)$ and white $\left(62.5 \times 10^{3} \mathrm{CFU} / \mathrm{g}\right)$ sorghum grains used as the main raw materials for the production of "té" and "mpedli" beers. The results suggest that the processing of both turbid beers using the traditional method are exposed to microbial contamination. Increase of microbial loads after soaking, adding of the supernatant (red beer only) and malted flour (white beer only) after the heating step means that control measures are needed to prevent contamination after these sensitive stages. Proper handling of raw materials, adequate implementation of heating and fermentation were found as effective critical control points. Training of producers on the hazards analysis and good manufacturing and hygiene practices have been suggested as strategies to improve the safety of indigenous beers.
\end{abstract}

Keywords: Northern Cameroon, sorghum, traditional beers, processing, microbial contamination, critical control point, food safety.
Published Online: April 08, 2021

ISSN: 2684-5199

DOI: $10.24018 /$ ejbio.2021.2.2.156

James Ronald Bayoï *

Department of Biological Sciences,

University of Maroua, Cameroon.

(e-mail: jabar982002@gmail.com)

François-Xavier Etoa

Department of Microbiology,

University of Yaoundé I, Cameroon.

(e-mail: fxetoa@yahoo.fr)

*Corresponding Author

\section{INTRODUCTION}

Indigenous drinks also named traditional beverages are drinks belonging to a particular area and developed by the people from that area using ancient techniques on locally available and homegrown raw materials [1]. These beverages have a relatively simple process of preparation and are often at times used as traditional remedies because some of them are believed to have medicinal properties [2]. Production of these beverages commonly involves either a simple nonmicrobial process or a microbial fermentation [3]. Fermentation of food is known as one of the oldest methods of food preparation and important means of preserving and introducing variety into the diet. The products obtained generally have a role in social gathering such as marriage, naming, and rain-making ceremonies [4]. Brewing technology is one of the oldest known food-fermentation processes. So, beer has been produced since ancient times and is most frequently consumed throughout the world [5]. In Africa, we have many different kinds of beer traditionally made from local cereal [6] and non-cereal [7] substrates, which are different from industrially beer produced in Western countries [4]. In Cameroon, traditional beers are either maize-based both called "Haa'a" in Centre and "Chaa'a" in North-west regions, or sorghum-based commonly known as "Bili bili" in the Northern regions, where are situated the hottest areas of the country [8]. In that arid area, precisely in the valley of the famous "Mandara" Mountains located in the Far-north region, we have two culturally embedded sorghum-based beers, the white "mpedli" and red "té" beers. Both traditional alcoholic beverages are an integral part of the socio-cultural life of the "Kapsiki" tribe because the white "mpedli" beer is assimilated to the female gender, while the red "té" beer is associated with male gender [9]. As most of African sorghum beers, both low-alcoholic fermented beverages are still rudimentary processed and the fermentation is done by uncontrolled inoculation. The white beer is made by fermenting the mixture obtained from brewed malt flour added to the cooked non-malted flour of sorghum ( $f u f u$ ) 
without the inoculation of any starter culture [10]. Whereas, the red beer is generally produced by fermenting sweetish wort (tè kwarhèni) from malted flour of sorghum, using a craft starter culture harvested from older preparation [11]. Because of their low cost, these traditional beers are cherished. They dominate in villages and the main cities markets of the Far-north region of Cameroon. As the consumption of these turbid beers is constantly rising up, concerns about the safety and hygiene of these drinks and their potential risk to the health of consumers are also increasing. The previous study undertaken on these traditional sorghum beers revealed a high load of microbial contamination and poor hygienic quality of the ready-to-serve products [10], [11]. Therefore, consumption of these indigenous beverages might be unsafe for the consumers. Indeed, the consumption of similar indigenous drinks has been incriminated in several cases of food poisoning and illness around the world. It has been reported that more than 2 million people all over the world, mostly children and elderly persons, die per year as a result of diseases caused by the consumption of contaminated food and water [2].

According to the literature, sorghum used as raw material during the production of both turbid beers are nutrient-rich and provides favorable conditions for the growth of both spoilage and pathogenic bacteria [12]. Furthermore, the rudimentary production processes coupled with unhygienic practices during the manufacturing of both indigenous beers may also provide potential ways of contamination. Consequently, both traditional sorghum beers appear as high microbiological and sanitary hazards. Thus, more empirical data regarding the nature of bacteria contained within the products, the potential sources of biological contamination, and effective control points during the processing are important if we need to upgrade the microbiological quality and the safety of both traditionally brewed beers. All these resources may be essential for the production of the traditional beers, which can potentially challenge the standardized and manufactured foreign beers in local, regional and international markets. To date, the few studies performed on these traditional beers only focused on the physicochemical and microbial characterization of the readyto-serve beverages [10], [11], while no research has undertaken to examine the microbiological quality of both traditional sorghum beers with emphasis on the different steps involved during the beer's production. So, the present study aimed to investigate the contamination hazards using simplified HACCP system and microbial changes during the processing of two culturally embedded sorghum-based beers brewed in the Far-north of Cameroon.

\section{MAteriALS AND METHODS}

\section{A. Production Sites of Sorghum-based Beers}

The red and white "kapsiki" beers were both sorghumbased beers used for this study. Different producers of these beverages were identified in Rhumzu, Rhumsiki, Mogode and Mokolo located at Mayo-Tsanaga Division in the FarNorth Region of Cameroon (Fig. 1). These sites were chosen because most of the producers of both studied beverages come from "Kapsiki" land situated in the Mandara
Mountains. This study resulted in close interaction with the producers-retailers and consumers. They were selected based on their location, environmental conditions production as well as the interest in participation. Twelve local producers were selected, three from each production sites listed above.

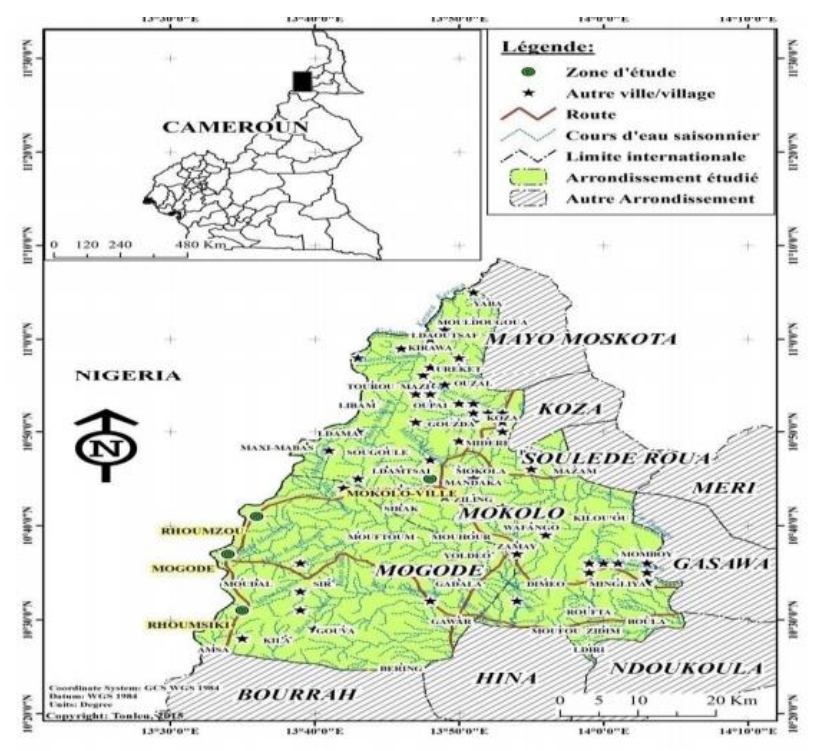

Fig. 1. Production sites (map transcript in French).

\section{B. Hazard Analysis}

Hazard analysis was conducted using HACCP system. Eight different producers, one by site for each sorghum "kapsiki" beer were requested. Producers were observed as they produced the indigenous beers. The hazard analysis consisted to: the evaluation of the raw materials used, the environment of production, beers preparation, and personal hygiene to identify potential sources of contamination. Based on the observations and discussion made during the preparation, detailed flowchart for "té" red "kapsiki" and "mpeldi" white "kapsiki" beers production were developed and potential sources of contamination were noted. The hazards of contamination, survival, and microbial growth were likely noted (Fig. 2 and 3) on each diagram as described by [13]. Samples were taken at different stages of preparation and subsequently tested for microbial quality.

\section{Samples Collection}

One hundred (100) grams of unmalted and malted sorghum (S. bicolor) grains (white and red varieties) were collected in sterile bags. Two hundred milliliters $(200 \mathrm{~mL})$ of liquid fractions were taken in duplicate at different stages during the production of each opaque beer. During the production of the sorghum white "mpedli" beer, the following samples were collected: (a) raw material (NMR), (b) malt (MR), (c) after settling of unmalted flour (MSH1), (d) after cooking of wetmilled (MSH2), (e) after adding malted flour (MSH3), (f) ready-to-serve product (FPw). During the processing of the red "té" beer, the following samples were harvested: (a) raw material (NMR), (b) malt (MR), (c) wet malted flour after the settling (MSH1), (d) after the first heating (MSH2), (e) after adding of supernatant and overnight cooling (Wo), (f) after heating of the sour wort $(\mathrm{Wb}),(\mathrm{g})$ ready-to-serve product (FPr). All the samples were collected in the sterile bottles, sealed, labelled, and were put into a separate sterile sampling bag. Samples were stored in an icebox container mid-filled 
with lump ice, and transported under cold regime to the laboratory for microbial assessment. A total of 48 and 56 samples were collected during the processing of white "mpedli" and red "té" beers, respectively.

\section{Microbiological Analysis and Identification}

The microbial loads of the sorghum grains (non-malted and malted) and liquids fractions collected during processing were evaluated using standard methods. Serial decimal dilutions $\left(10^{-1}\right.$ to $\left.10^{-6}\right)$ were done using $9 \mathrm{~mL}$ of sterile saline solution $(0.85 \% \mathrm{NaCl})$ and $1 \mathrm{~mL}$ of each sample collected. Between two successive dilutions, the previous suspension was vortexed at $350 \mathrm{rev} / \mathrm{min}$ for 2-3 min before being used for the preparation of the next dilution. At the end, the appropriate dilution was chosen and $1 \mathrm{~mL}$ of the aliquot was plated in specific solid medium [2]. The different analytical methods and standards used for counting of germs contained in samples are indicated in Table I. After the incubation of seeded plates, enumeration of colonies was carried out and the results were calculated and expressed in colony-forming unit $(\mathrm{CFU})$ per milliliter $(\mathrm{mL})$ or gram $(\mathrm{g})$ according to the formula [2]:

$\mathrm{CFU} / \mathrm{mL}(\mathrm{g})=$ number of colonies/dilution $\times$ seeding volume

The confirmation of Coliforms and E. coli was carried out using gram staining test, lactose fermentation test, and characteristics of colonies.

TABLE I: CULTURE MEDIA AND TEMPERATURE/TiME INCUBATION USED FOR MICROBIAL ANALYSIS OF THE BEER SAMPLES

\begin{tabular}{|c|c|c|c|c|}
\hline Flora & Standards & Culture media & $\begin{array}{l}\text { Temperature } \\
\text { and time of } \\
\text { incubation }\end{array}$ & References \\
\hline $\begin{array}{c}\text { Total } \\
\text { aerobic } \\
\text { bacteria }\end{array}$ & $\begin{array}{c}\text { ISO } \\
4833: 2003\end{array}$ & $\begin{array}{l}\text { Plate Count agar } \\
\text { (PCA, Difco, } \\
\text { BD, Sparks, } \\
\text { MD) }\end{array}$ & $\begin{array}{c}30^{\circ} \mathrm{C} \text { for } 24 \\
\text { to } 48 \mathrm{~h}\end{array}$ & [14] \\
\hline Total fungi & $\begin{array}{c}\text { ISO } \\
21527-2: \\
2008\end{array}$ & $\begin{array}{c}\text { Potato dextrose } \\
\text { agar (PDA, } \\
\text { Difco, BD) }\end{array}$ & $\begin{array}{c}25^{\circ} \mathrm{C} \text { for } 5 \\
\text { days }\end{array}$ & [15] \\
\hline $\begin{array}{l}\text { Total } \\
\text { coliforms } \\
\text { count }\end{array}$ & $\begin{array}{c}\text { ISO } \\
4832: 2006\end{array}$ & $\begin{array}{c}\text { Eosine } \\
\text { Methylene Blue } \\
\text { agar (EMB, } \\
\text { Oxoid) }\end{array}$ & $\begin{array}{c}35^{\circ} \mathrm{C} \text { for } 24 \\
\mathrm{~h}\end{array}$ & [16] \\
\hline $\begin{array}{l}\text { Fecal } \\
\text { coliforms } \\
\text { count }\end{array}$ & $\begin{array}{l}\text { ISO } 9308- \\
1: 2000\end{array}$ & $\begin{array}{c}\text { Eosine } \\
\text { Methylene Blue } \\
\text { agar (EMB, } \\
\text { Oxoid) }\end{array}$ & $\begin{array}{c}44^{\circ} \mathrm{C} \text { for } 24 \\
\mathrm{~h}\end{array}$ & [17] \\
\hline E. coli & $\begin{array}{l}\text { ISO } 9308- \\
1: 2000\end{array}$ & $\begin{array}{c}\text { Eosine } \\
\text { Methylene Blue } \\
\text { agar (EMB, } \\
\text { Oxoid) }\end{array}$ & $\begin{array}{c}46^{\circ} \mathrm{C} \text { for } 24 \\
\mathrm{~h}\end{array}$ & [17] \\
\hline $\begin{array}{c}\text { Total } \\
\text { mesophilic } \\
\text { spore- } \\
\text { forming } \\
\text { bacteria }\end{array}$ & $\begin{array}{c}\text { SP-VG } \\
\text { M008 } \\
(3): 1998\end{array}$ & $\begin{array}{l}\text { Bromocresol } \\
\text { Purple glucose } \\
\text { agar }\end{array}$ & $\begin{array}{c}35^{\circ} \mathrm{C} \text { for } 48 \\
\mathrm{~h}\end{array}$ & [18] \\
\hline $\begin{array}{c}\text { Total } \\
\text { thermophilic } \\
\text { spore- } \\
\text { forming } \\
\text { bacteria }\end{array}$ & $\begin{array}{l}\text { SP-VG } \\
\text { M008 } \\
(3): 1998\end{array}$ & $\begin{array}{l}\text { Bromocresol } \\
\text { Purple glucose } \\
\text { agar }\end{array}$ & $\begin{array}{c}55^{\circ} \mathrm{C} \text { for } \\
48 \mathrm{~h}\end{array}$ & [18] \\
\hline
\end{tabular}

\section{E. Statistical Analysis}

All measurements were repeated three times, and Statgraphics (Technologies Inc., Virginia, USA) Centurion
16.1 software was used for the statistical analysis of the raw data obtained from the microbiological analysis. Means of microbial loads obtained from samples analysis were compared using one-way ANOVA (Analysis of Variance). Tukey's Honestly Significant Difference (HSD) test was run to discriminate pairs of means significantly different at $\mathrm{p}<0.05$. Correlations between the different microbiological parameters were achieved by Pearson's coefficient (r) at a significance of $\mathrm{p}<0.05$ using XLSTAT Version 2007.8.04 software (Addinsoft, New York, NY, USA).

\section{RESULTS}

\section{A. Hazards and Critical Control Point Analysis (HACCP) of} Indigenous Sorghum Beers Brewed in Northern Cameroon

Fig. 2 displays the flowchart diagrams and hazards and critical control point during the production of the indigenous beers, red "té" and white "mpedli". This Figure reveals that both sorghum beers imply three main stages such as malting, mashing and fermentation. Given that the red "té" beer is a noble beer generally brewed by men and only good quality grains are considered for its production. All the sorghum grains involved for preparation of red beer are malted, whereas most of the grains involved in the white beer production are used in the unmalted form. Furthermore, fermentation of the red beer requires the use of traditional non-selective starter, yeasts as shown in the picture $\mathrm{j}$ of Fig. 3 , whereas no starter is required for fermentation of the white beer, which starts spontaneously. Hazards analysis of the red beer production showed that the raw material, water used (Fig. 2d), sun drying, re-using of supernatant, cooling, sieving may be considered as stages where we could likely have hazards of contamination. Overnight cooling, cooling in open-air and fermentation (as shown in Fig. $3 \mathrm{f}$ and 2k) may be stages where we could observe hazards of microbial growth. Raw material, water used, cooling and handkneading were considered as material and processing steps where hazards of contamination might be observed during production of the white "mpedli" beer. The cooking of the wet unmalted sorghum flour was identified as hazards of survival during the processing of the same beer. Handling of malting and sun drying (as shown in pictures a-c of Fig. 3), heating (shown in picture e of Fig. 3) and fermentation processes were identified as the critical control points (CCP) which need to be controlled and optimized for the safety quality of both indigenous beers. Figure 3 shows that the production of both opaque beers takes place in an unhygienic environment using rudimentary equipment without consideration for Good Manufacturing Practice (GMP).

\section{B. Changes in the Microbial Content at Different Stages of Production of the Indigenous Sorghum Beers}

The aerobic plate counts in the raw materials (unmalted grains), semi-processed products (malt, mashe, sour wort, boiled wort) and the final products (fermenting state) are shown in Fig. 4. All the samples displayed a detectable level of aerobic plate count (APC). The malted sorghum $\left(13.5 \times 10^{3} \mathrm{CFU} / \mathrm{mL}\right)$ and ready-to-serve red "té" beer $\left(45.5 \times 10^{3} \mathrm{CFU} / \mathrm{mL}\right)$ were by far more contaminated than the non-malted sorghum $\left(0.16 \times 10^{3} \mathrm{CFU} / \mathrm{mL}\right)$ and the white "mpedli" beer $\left(5.2 \times 10^{3} \mathrm{CFU} / \mathrm{mL}\right)$. We also observed that 
APC was significantly increased at the malting step during the production of the red "té" beer. We noticed a great rise of the aerobic bacteria loads after the overnight cooling $\left(1.95 \times 10^{5} \mathrm{CFU} / \mathrm{mL}\right)$ and quenching of the unmalted raw $\left(6.6 \times 10^{5} \mathrm{CFU} / \mathrm{mL}\right)$ during the production of red "té" and white "mpedli" beers respectively. After each heating and cooking stage, we had a significant $(p<0.05)$ decrease in the APC loads.

Changes in fungi loads during artisanal processing of turbid "té" and "mpedli" sorghum beers are summarized in
Fig. 5. We noticed that the raw materials used for the production of both traditional sorghum beers were weakly contaminated by fungi. However, we observed a high fungi content of the red sorghum grains during malting $\left(2.2 \times 10^{4}\right.$ $\mathrm{CFU} / \mathrm{mL}$ ) and the wet unmalted flour from white sorghum grain $\left(8.5 \times 10^{4} \mathrm{CFU} / \mathrm{mL}\right)$. There was a significant $(\mathrm{p}<0.05)$ increase of the fungal load in the ready-to-serve red "té" beer $\left(1.5 \times 10^{4} \mathrm{CFU} / \mathrm{mL}\right)$ and a remarkable decrease in fungi content during the mashing steps occurred at time of the production of the white "mpedli" beer.
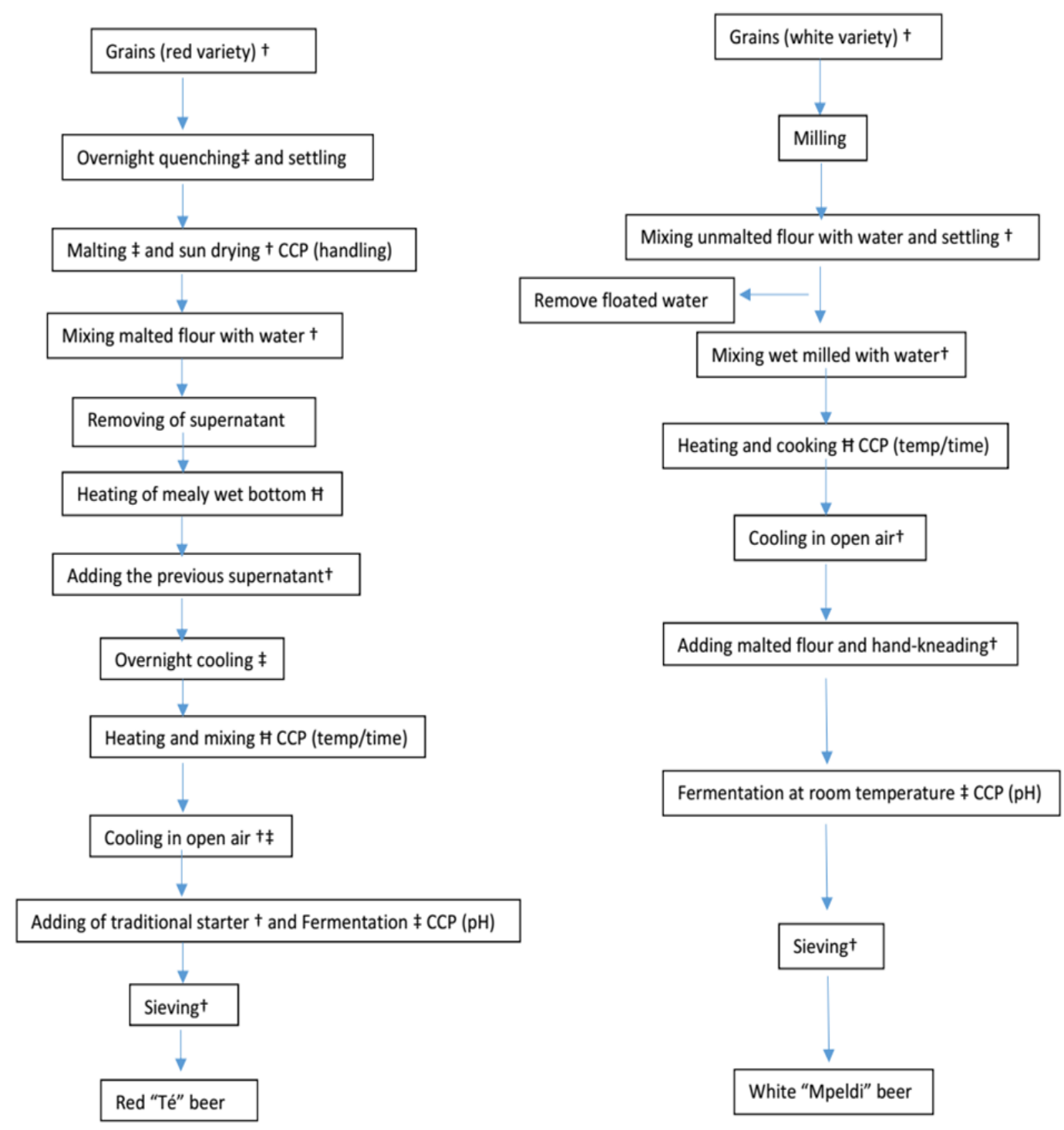

Fig. 2. Flowchart diagrams and hazards analysis of preparation of the red "té" and white "mpedli" sorghum beers. Legend: (†): Hazard of contamination; (H): Hazard of survival; ( $\$$ : Hazard of microbial growth; CCP: Critical Control Point. 


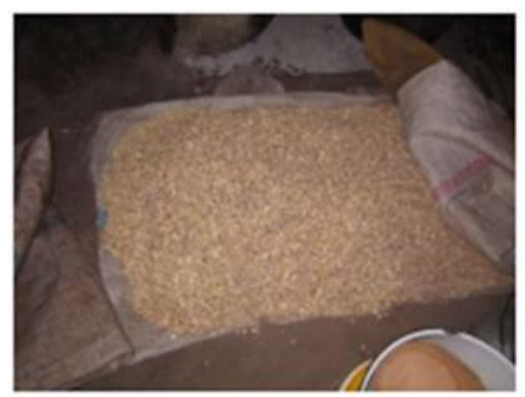

(a)

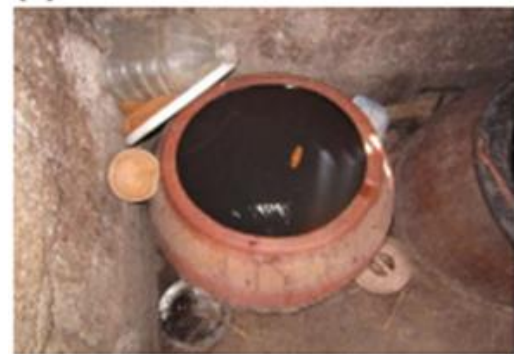

(d)

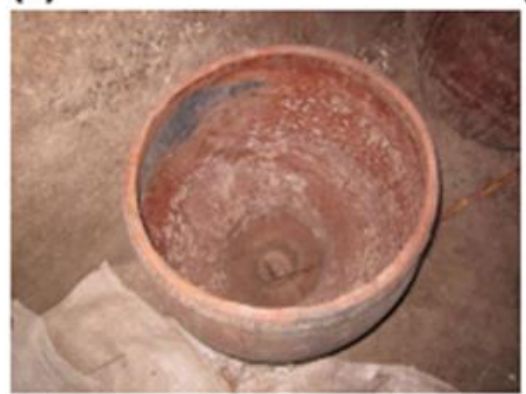

(g)

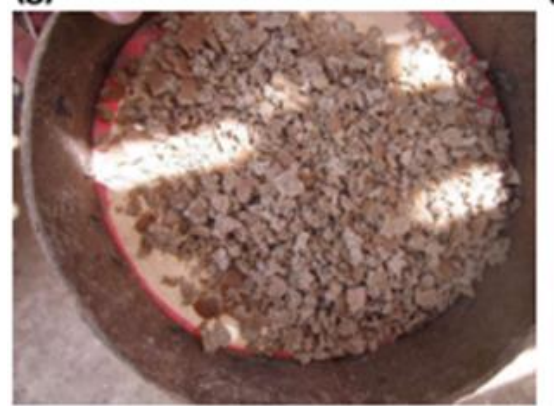

(j)

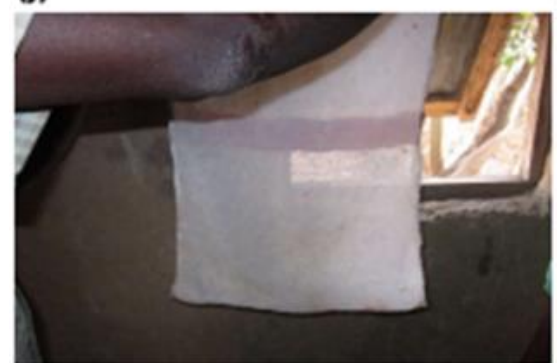

(m)

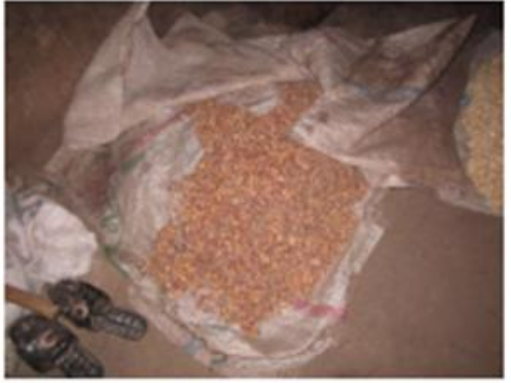

(b)

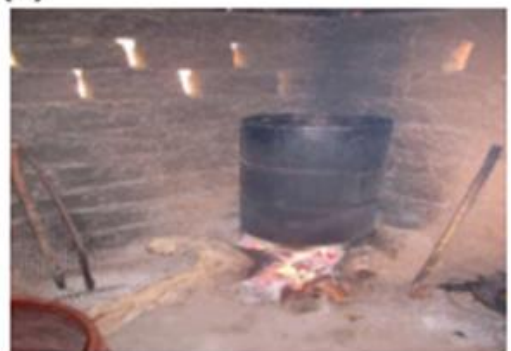

(e)

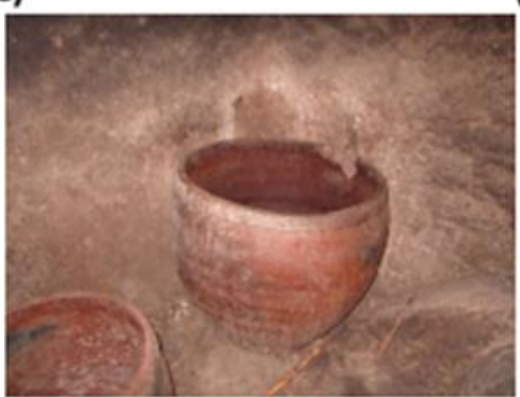

(h)

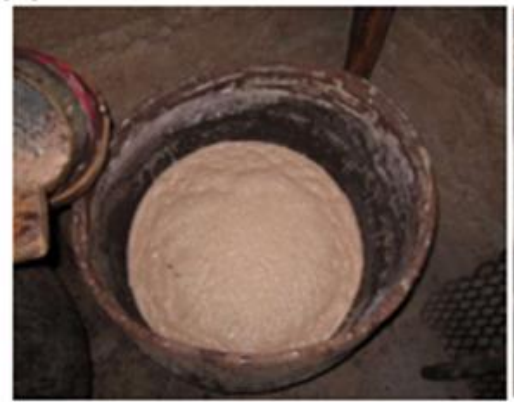

(k)

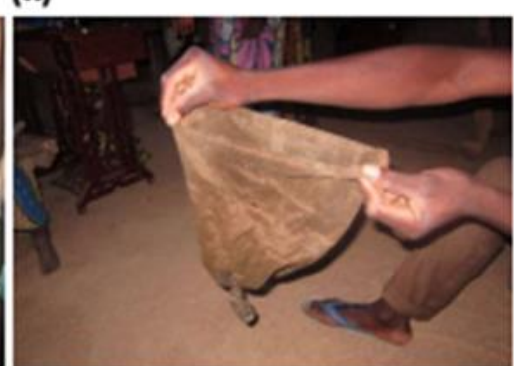

(n)

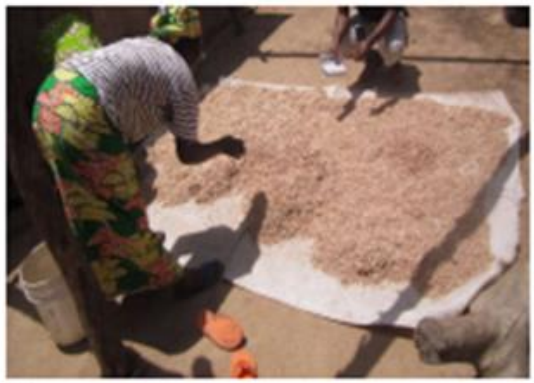

(c)

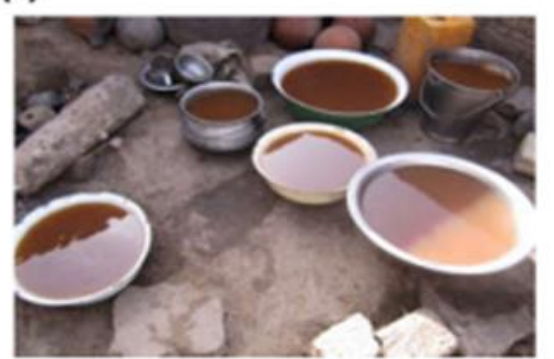

(f)

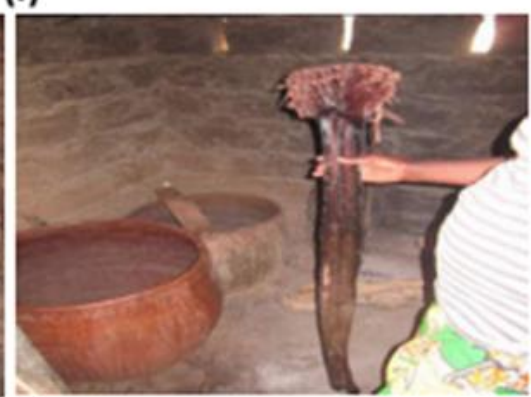

(i)

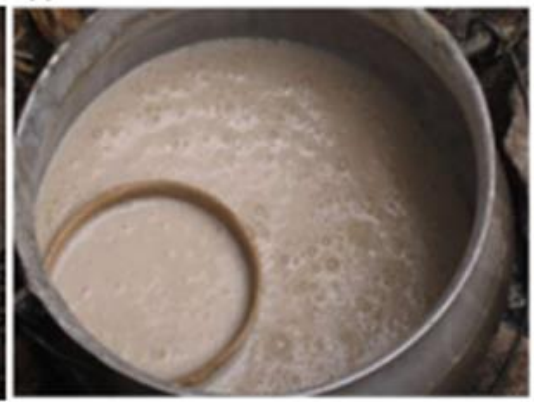

(I)

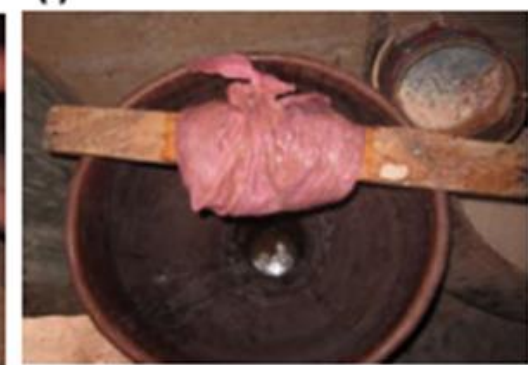

(o)

Fig. 3. Illustration of the materials and some main stages involved during processing of Cameroonian sorghum-based opaque beers.

Legend: a-b: malting process and environment; c: sun drying; $d$ : water used for preparation; e: heating process and the mixing stick (besides the barrel on fire); f: cooling process; g-h: earthenware used for wort cooking and fermentation; j: wild starter; k-1: fermenting wort during production of red "té" and white "mpedli" beers; m-o: filtration system 

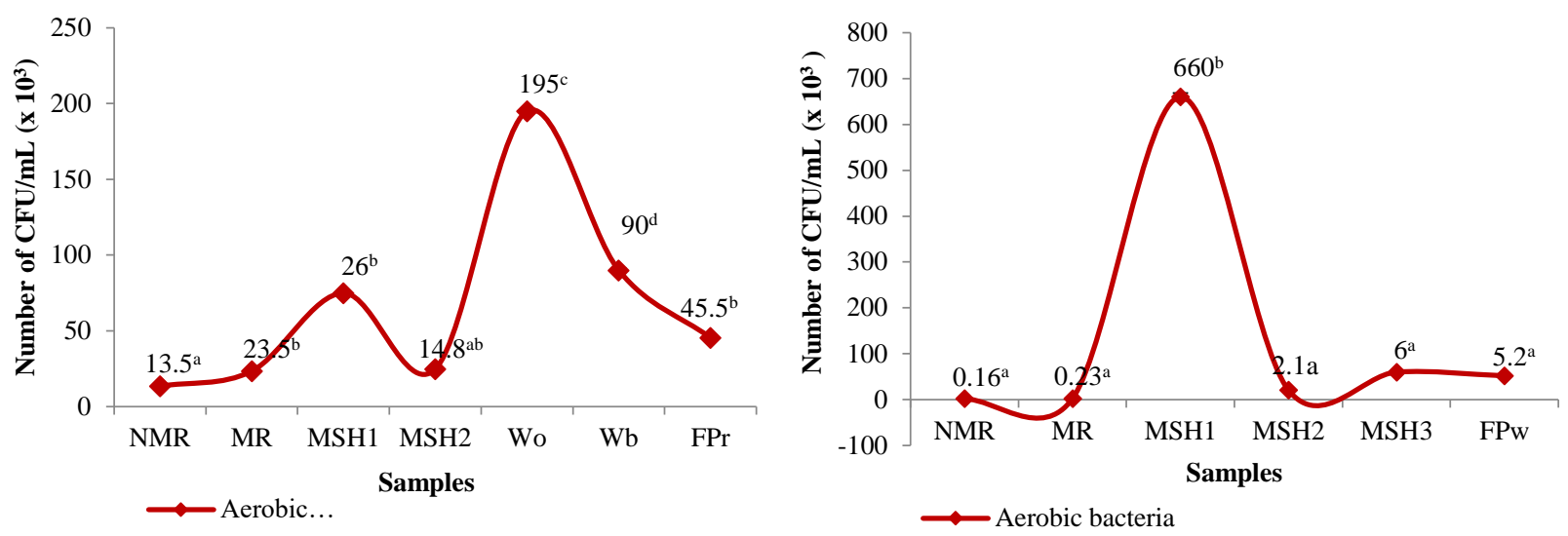

Fig. 4. Aerobic and mesophilic plate count during the traditional production of the red "té" beer (left) and the white "mpedli" beer (right) in Northern Cameroon. Legend, NMR: non malted grains, MR: malted grains, MSH1: wet unmalted flour (white beer) and wet malted flour (red beer), MSH2: after heating, MSH3: after adding of malt (white beer only), Wo: after heating and overnight cooling (red beer only), Wb: after boiling of sour wort (red beer only), FPr and FPw: ready-to-serve red and white beers respectively. Mean values followed by the same letter are not significantly different at $\mathrm{p}<0.05$.
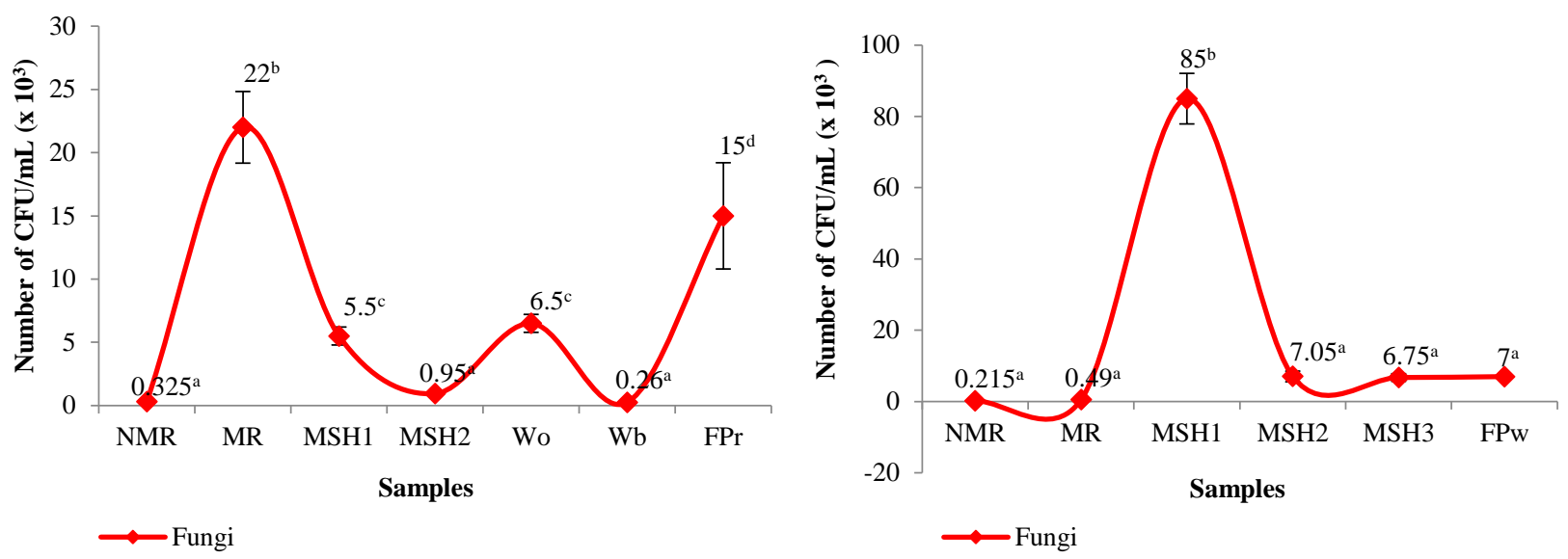

Fig. 5. Fungi loads at some stages during the traditional production of the red "té" beer (left) and the white "mpedli" beer (right) in Northern Cameroon Legend, NMR: non malted grains, MR: malted grains, MSH1: wet unmalted flour (white beer) and wet malted flour (red beer), MSH2: after heating, MSH3: after adding of malt (white beer only), Wo: after heating and overnight cooling (red beer only), Wb: after boiling of sour wort (red beer only), FPr and FPw: ready-to-serve red and white beers respectively. Mean values followed by the same letter are not significantly different at $\mathrm{p}<0.05$.

Fig. 6 shows mesophilic and thermophilic spores' counts at different stages of both red "té" and white "mpedli" processing. All the samples revealed a high detectable level of the mesophilic spore-forming bacteria. The unmalted materials involved in the production of the red "té" beer $\left(3.8 \times 10^{4} \mathrm{CFU} / \mathrm{mL}\right)$ and white "mpedli" beer $\left(6.25 \times 10^{4} \mathrm{CFU} / \mathrm{mL}\right)$ displayed the most important contents of spore forming bacteria. However, we observed a significant $(\mathrm{p}<0.05)$ drop in mesophilic spores contents of $1.75 \times 104 \mathrm{CFU} / \mathrm{mL}$ and $5.3 \times 10^{3} \mathrm{CFU} / \mathrm{mL}$ for the malt used for the production of red "té" and white "mpedli" beers respectively. The thermophilic bacterial spores were poorly present in most of the collected samples. Nevertheless, we noticed a significant increase $(\mathrm{p}<0.05)$ after the boiling, during the processing of the red beer.

Total and thermo-tolerant Coliforms at different stages of both red "té" and white "mpedli" processing are shown in Fig. 7. Total Coliforms count were ranged from $0.51 \times 10^{3} \mathrm{CFU} / \mathrm{mL}$ to $7.2 \times 10^{3} \mathrm{CFU} / \mathrm{mL}$ in the red "té" beer and malt respectively. This result revealed the key role of some stages (heating and fermentation) in the decrease of Coliforms bacteria during the production of the red beer. The same tendency was observed during the production of the white "mpedli" beer, where the microbial load varied from $0.48 \times 10^{3} \mathrm{CFU} / \mathrm{mL}$ to $3 \times 10^{3} \mathrm{CFU} / \mathrm{mL}$ in the white "kapsiki" beer and the wet unmalted flour from white sorghum grain respectively. We noticed a global decrease in total coliforms content from mashing steps up to the final product. The thermotolerant Coliforms were strongly revealed in the malt $\left(2 \times 10^{3} \mathrm{CFU} / \mathrm{mL}\right)$ used for producing of the red "kapsiki" beer and the wet unmalted flour $\left(5.2 \times 10^{2} \mathrm{CFU} / \mathrm{mL}\right)$ used during the manufacturing of the traditional white sorghum beer. During processing, there was a progressive decrease in thermotolerant coliforms count, just after the malting stage up to the production of the ready-to-serve red beer. Generally, we noticed that coliforms contamination was more pronounced during the production of the red "té" beer than the manufacturing of the white "mpedli" beer.

Figure 8 shows $E$. coli content of samples collected during the traditional processing of both red "té" and white "mpedli" sorghum beers brewed in Northern Cameroon. This figure reveals that $E$. coli appeared in all the samples collected during the production of both indigenous sorghum beers. During the processing of the red "té" beer, the highest $E$. coli loads were obtained in the malt $\left(13 \times 10^{2} \mathrm{CFU} / \mathrm{mL}\right)$ and the wet malted flour $\left(13.6 \times 10^{2} \mathrm{CFU} / \mathrm{mL}\right)$. After quenching of unmalted flour $\left(3.55 \times 10^{2} \mathrm{CFU} / \mathrm{mL}\right)$ and mixing of malted flour to the cooked non-malted flour $\left(3.8 \times 10^{2} \mathrm{CFU} / \mathrm{mL}\right)$ were identified as the most semi-processed samples contaminated by $E$. coli during production of the white "mpedli" beer. We 
also observed moderate contamination by $E$. coli of both red "té" beer $\left(0.69 \times 10^{2} \mathrm{CFU} / \mathrm{mL}\right)$ and white "mpedli" beer

$\left(1.1 \times 10^{2} \mathrm{CFU} / \mathrm{mL}\right)$ obtained after fermentation.

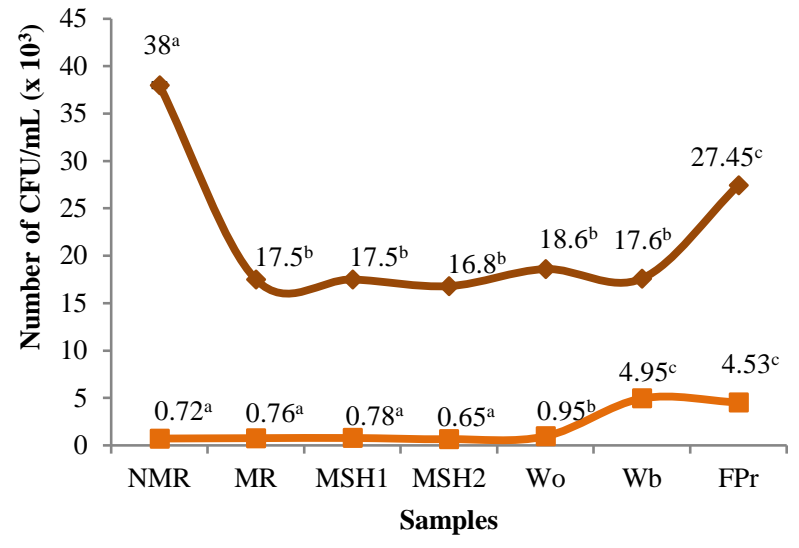

$\longrightarrow$ Mesophilic spores $\longrightarrow$ Thermophilic spores

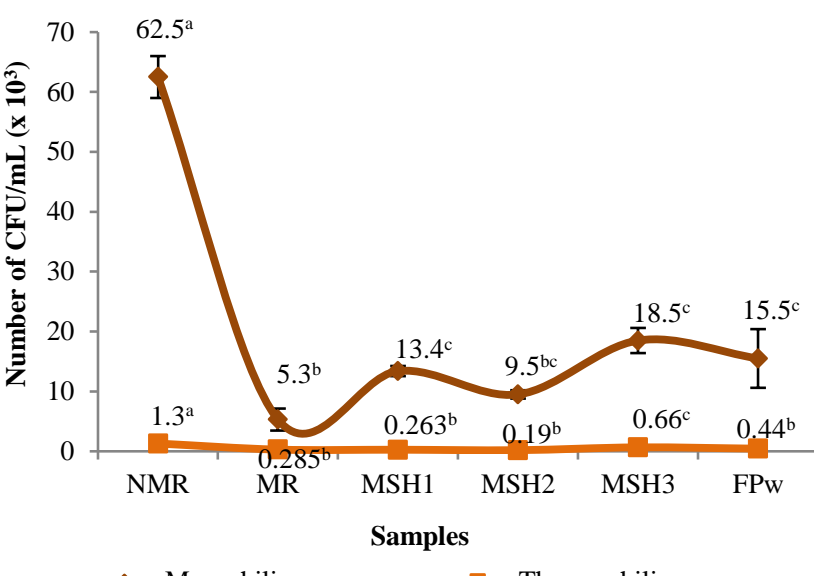

Mesophilic spores $\quad \longrightarrow$ Thermophilic spores

Fig. 6. Contents in spore-forming bacteria during the traditional production of the red "té" beer (on the left) and the white "mpedli" beer (on the right) in Northern Cameroon. Legend, NMR: non malted grains, MR: malted grains, MSH1: wet unmalted flour (white beer) and wet malted flour (red beer), MSH2: after heating, MSH3: after adding of malt (white beer only), Wo: after heating and overnight cooling (red beer only), Wb: after boiling of sour wort (red beer only), FPr and FPw: ready-to-serve red and white beers respectively. Mean values followed by the same letter (a, b, c) are not significantly different at $\mathrm{p}<0.05$.
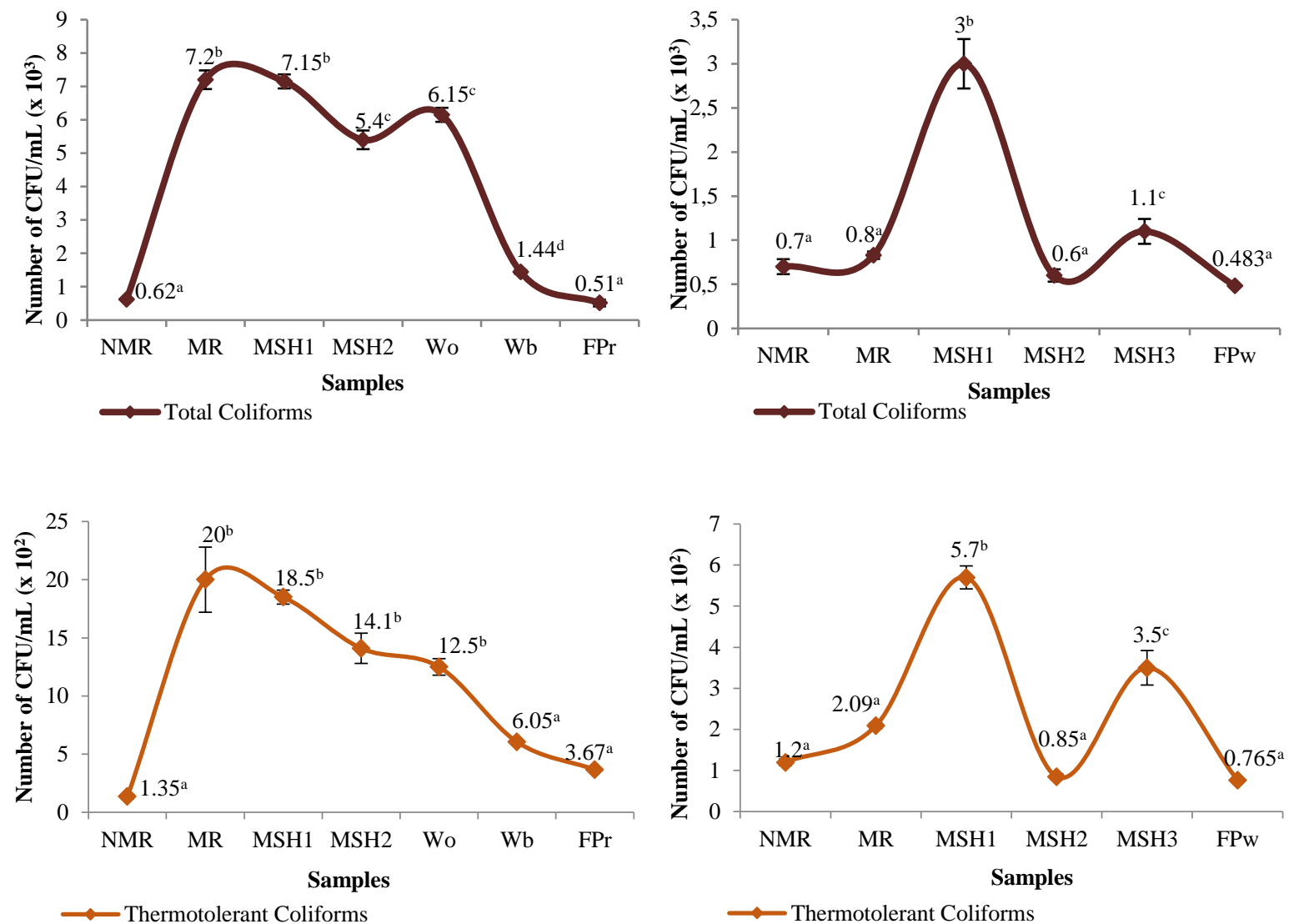

Fig. 7. Total Coliforms (up) and thermotolerant Coliforms (down) count during the traditional processing of the red "té" beer (on the left) and the white "mpedli" beer (on the right) in Northern Cameroon. Legend, NMR: non malted grains, MR: malted grains, MSH1: wet unmalted flour (white beer) and wet malted flour (red beer), MSH2: after heating, MSH3: after adding of malt (white beer only), Wo: after heating and overnight cooling (red beer only), Wb: after boiling of sour wort (red beer only), FPr and FPw: ready-to-serve red and white beers respectively. Mean values followed by the same letter (a, b, c) are not significantly different at $\mathrm{p}<0.05$ 

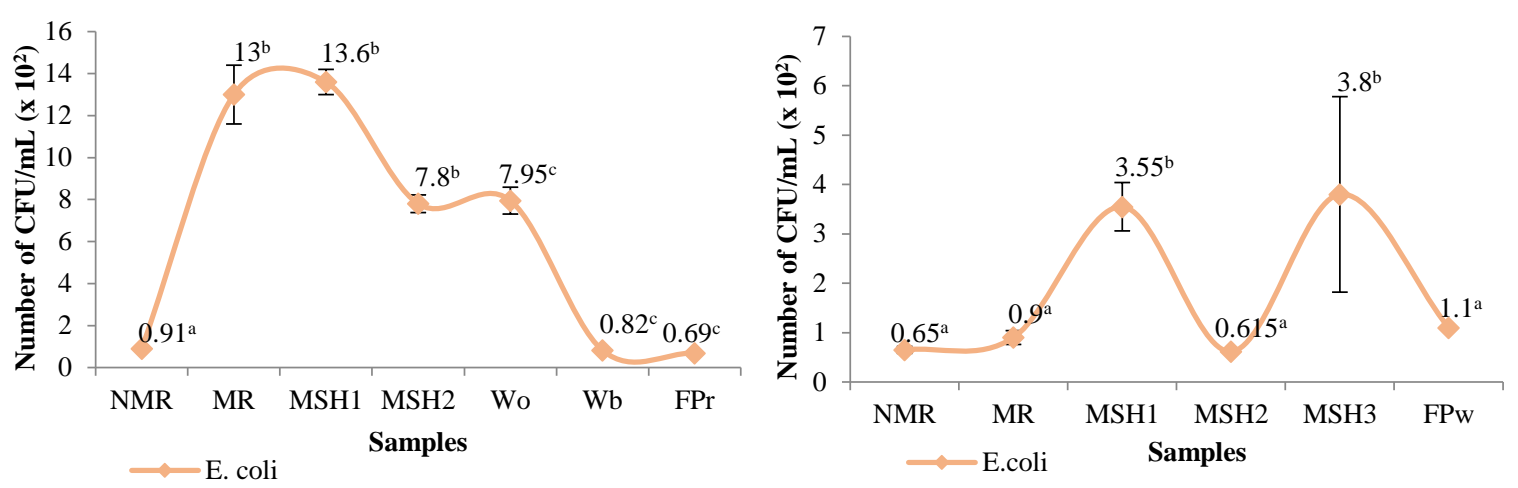

Fig. 8. Changes in E. coli loads during the traditional production of the red "té" beer (on the left) and the white "mpedli" beer (on the right) in Northern Cameroon. Legend, NMR: non malted grains, MR: malted grains, MSH1: wet unmalted flour (white beer) and wet malted flour (red beer), MSH2: after heating, MSH3: after adding of malt (white beer only), Wo: after heating and overnight cooling (red beer only), Wb: after boiling of sour wort (red beer only), FPr and FPw: product in fermenting state. Mean values followed by the same letter (a, b, c) are not significantly different at $\mathrm{p}<0.05$.

\section{Correlation Analysis}

Tables II and III present the correlation coefficients between microbial loads during the processing of both white and red indigenous sorghum beers, respectively. During the production of the white "mpedli" beer, we noticed very strong positive correlations between bacteria and fungi loads $(\mathrm{r}=0.998 ; \mathrm{p}<0.01)$, total coliforms and bacteria counts $(r=0.974 ; p<0.01)$ from one side, and fungi loads $(r=0.967$; $\mathrm{p}<0.01)$ from the other side, mesophilic and thermophilic spore-forming bacteria counts $(r=0.962 ; \mathrm{p}<0.01)$, and total and thermotolerant (fecal) coliforms counts ( $\mathrm{r}=0.943$; $\mathrm{p}<0.01$ ). Both strong positive correlations were found between thermotolerant (fecal) coliforms count and bacteria load $(r=0.862 ; p<0.05)$ on one hand, fecal coliforms count and fungi count $(\mathrm{r}=0.845 ; \mathrm{p}<0.05)$ on the other hand. Another positive and significant correlation between fecal coliforms and $E$. coli loads $(\mathrm{r}=0.876$; $\mathrm{p}<0.05)$ has been observed. However, poor and negative correlations have been noticed between bacteria and spore-forming bacteria from mesophilic $(\mathrm{r}=-0.202 ; \mathrm{p}>0.05)$ and thermophilic $(\mathrm{r}=-0.323 ; \mathrm{p}>0.05)$ species.

TABLE II: CORRELATION COEFFICIENTS (R) BETWEEN MICROBIAL

Counts During PRoduction OF THE WHITE SORGHUM BEER

\begin{tabular}{cccccccc}
\multicolumn{6}{c}{ COUNTS DURING PRODUCTION OF THE WHITE SORGHUM BEER } \\
\hline & Bacteria & Fungi & MSFB & TSFB & To Col & Fe Col & EC \\
\hline Bacteria & 1 & & & & & & \\
Fungi & $0.998^{\mathrm{b}}$ & 1 & & & & & \\
MSFB & -0.202 & -0.219 & 1 & & & & \\
TSFB & -0.323 & -0.349 & $0.962^{\mathrm{b}}$ & 1 & & & \\
To Col & $0.974^{\mathrm{b}}$ & $0.967^{\mathrm{b}}$ & -0.178 & -0.266 & 1 & & \\
Fe Col & $0.862^{\mathrm{a}}$ & $0.845^{\mathrm{a}}$ & -0.227 & -0.227 & $0.943^{\mathrm{b}}$ & 1 & \\
EC & 0.639 & 0.615 & -0.221 & -0.132 & 0.718 & $0.876^{\mathrm{a}}$ & 1 \\
\hline
\end{tabular}

Pearson's coefficients (r) having as superscript letter (a) are statistically significant at $\mathrm{p}<0.05$. Pearson's coefficients (r) having as superscript letter (b) are statistically significant at $\mathrm{p}<0.01$. Notes. Bacteria: total mesophilic aerobic bacteria; MSFB: mesophilic spore-forming bacteria; TSFB: thermophilic spore-forming bacteria; To Col: total coliforms; Fe Col: fecal (thermotolerant) coliforms; EC: E. coli.

Table III shows that during the manufacturing of the red "té" beer, positive and very significant correlations have been observed between total coliforms and thermotolerant coliforms $(\mathrm{r}=0.970 ; \mathrm{p}<0.01)$, total coliforms and E. coli ( $\mathrm{r}=0.971 ; \mathrm{p}<0.01)$, and fecal coliforms and $E$. coli $(\mathrm{r}=0.974 ; \mathrm{p}<0.01)$. Positive and significant correlation has been found between fecal coliforms and mesophilic sporeforming bacteria $(r=0.764 ; p<0.05)$. Furthermore, weak and negative correlation between bacteria and mesophilic sporeforming bacteria $(r=-0.373 ; p>0.05)$ has been revealed during processing of the red indigenous sorghum beer.

TABLE III: CORRELATION COEFFICIENTS (R) BETWEEN MICROBIAL COUNTS DURING PROCESSING OF THE TRADITIONAL RED SORGHUM BEER

\begin{tabular}{cccccccc}
\hline & Bacteria & Fungi & MSFB & TSFB & To Col & Fe Co & EC \\
\hline Bacteria & 1 & & & & & & \\
Fungi & -0.140 & 1 & & & & & \\
MSFB & -0.373 & -0.152 & 1 & & & & \\
TSFB & 0.066 & 0.010 & 0.020 & 1 & & & \\
To Col & 0.256 & 0.295 & -0.710 & -0.668 & 1 & & \\
Fe Co & 0.104 & 0.392 & $-0.764^{\mathrm{a}}$ & -0.551 & $0.970^{\mathrm{b}}$ & 1 & \\
EC & 0.092 & 0.378 & -0.620 & -0.670 & $0.971^{\mathrm{b}}$ & $0.974^{\mathrm{b}}$ & 1 \\
\hline
\end{tabular}

Pearson's coefficients (r) having as superscript letter (a) are statistically significant at $\mathrm{p}<0.05$. Pearson's coefficients (r) having as superscript letter (b) are statistically significant at $\mathrm{p}<0.01$. Notes. Bacteria: total mesophilic aerobic bacteria; MSFB: mesophilic spore-forming bacteria; TSFB: thermophilic spore-forming bacteria; To Col: total coliforms; Fe Col: fecal (thermotolerant) coliforms; EC: E. coli.

\section{DISCUSSION}

The strong increase in aerobic plate count and fungi, observed at the end of the steeping of the sorghum flour used for the production of white beer "mpedli" would be due to the high moisture content, the presence of nutrients and contaminant microorganisms from the raw material. Besides, the massive prevailing in the total aerobic plate count in the sour mash would likely have resulted from the addition of the contaminated supernatant in the soaked and precooked malted flour. The decrease in the total flora of the boiled wort and red "té" beer would be linked to the heat treatment used for cooking of the sour wort, then the production of alcohol and acidification occurring during fermentation of the boiled and sweet wort. The same tendency was observed for other microorganisms followed during the production of both opaque sorghum beers. Heat treatment and fermentation of food do not only improves the taste, odor, and digestibility, they also reduce the microbial load, improves shelf life by inhibiting bacteria, yeasts, and moulds which promote spoilage and poisoning. Thus, both heat treatment and fermentation are practices aimed at upgrading the overall safety of food, so they can be effectively considered as a critical control point (CCP) and they must be checked and 
optimized to prevent microbial contamination. The significant increase in fungal flora in the malt from red sorghum grains would result from the humid conditions, which do not only favours the germination of grains, but also for the growth of fungi. Indeed, during malting, the producers of malt carry out permanent moistening of the raw material to increase the relative humidity necessary for the germination of the grains, this humid environment is very conducive for the multiplication of yeasts and moulds. The moderate increase in the fungal load in the sour wort obtained at the end of the second decantation and the first heating-cooking during the processing of the red "té" beer would be due to a recontamination of the boiled fraction after addition of the supernatant from soaked and settled malted flour that may be contaminated by fungi and had not undergone any heat treatment. The impressive increase in fungal flora in the final product, red "te" beer goes in agreement with the results obtained by [19] during the production of "bili-bili", an indigenous beer made from millet in Chad. These authors reported that increase of fungi in the ready-to-serve traditional beer was linked to the exogenous supply of this flora during the addition of the wild starter. Fortunately, during the production of red sorghum "té" beer, we noticed that the producers added a craft dried ferment as illustrated in picture $\mathrm{j}$ of Fig. 3. The significant presence of the mesophilic spore-forming bacteria would indicate strong contamination of high dried sorghum grains (moisture content much lower than $13 \%$, data not shown) used as the raw material for the traditional processing of the red and white "kapsiki" beers. It was reported that dehydrated products are frequently contaminated with spore-forming bacteria from Bacillus [20], [21]. These contaminations are often amplified by certain stages of the manufacturing process. For example, the sun drying step used during the production of traditional beers makes it possible to concentrate both the substrate and the biological contaminants contained in the raw material [22]. By their ability to adhere and resist, bacterial spores can contaminate and persist in the food processing environment [23]. Some species of Bacillus genus have been found in equipment, throughout the manufacturing chain, in water, air and packaging material [22]. The presence of mesophilic bacteria spores in manufactured food has been reported to be associated with the initial contamination of ingredients [24]. The significant decrease in the mesophilic spore-forming flora observed after malting, during the production of both "kapsiki" beers could be explained by the high moisture content of the sprouted grains and the relative high humidity during the germination step. Even if, the dried nature of sorghum grains will promote the sporulation of bacteria during malting, the rehydration of the grains will lead to an increase in their moisture content and thus facilitates the germination of bacterial spores and their outgrowth into vegetative cells, with the result being a decrease in bacterial spores and an increase of the vegetative cells in the malt. This could justify the significant increase at the same time of the total aerobic plate count in the malt obtained from the red sorghum used as a raw material for the traditional processing of the red "té" beer. We observed a massive presence of mesophilic spore-forming bacteria flora in each of the readyto-serve "kapsiki" beers. This is the result of the extraordinary properties of resistances of bacterial spores to physical and chemical agents that confer them a ubiquitous character and ability to easily contaminate and spoil food and beverages [25]. Different Bacillus species have been found in drinks. The most identified mesophilic spore-forming bacteria species in beverages are $B$. cereus, $B$. circulans, $B$. coagulans, B. licheniformis, B. megaterium, B. pumilus, $B$. sphaericus, and B. subtilis species [26], [27]. The spoilage of beverages caused by Bacillus is mainly sensorial defects such as unpleasant flavors and visual alterations [28]. The presence of Coliforms and E. coli after heating, boiling or cooking step during the production of both indigenous "kapsiki" beers may be linked to the poor hygienic quality of water used (as shown by picture d of Fig. 3), equipment involved during the production (Fig. $3 \mathrm{~g}, \mathrm{~h}, \mathrm{i}, \mathrm{n}$, and o), an open-air system used for cooling the boiled wort (Fig. $3 \mathrm{f}$ ), and the processing environment (pictures a-c, e of Fig. 3). This is in line with previous reports on the traditional processing of fermented condiments and "kunun-zaki", a non-alcoholic cereal-based beverage, both made in Nigeria [13], [29].

As many traditional fermented beverages are made from cereals, fermentation of both red "té" and white "mpedli" beers is spontaneous [6], and dominated by lactic and alcoholic fermentation [30]. Spontaneous fermentation generally results from the competitive activities of different microorganisms, and strains that are better suited and have the highest growth rate will dominate at particular stages of the process. Studies carried out on fermented cereal-based drinks have shown that lactic and alcoholic ferments come from malt (wheat, sorghum or millet) and fermentation equipment (shown in Fig. 3) respectively [31]. The main lactic acid bacteria responsible for the acidification of indigenous cereal-based beers are Lactobacillus (the predominant genus), Lactococcus, Leuconostoc and Pediococcus [32], [33]. Most of the yeasts involved in alcoholic fermentation belong to the Saccharomyces genus. Several authors reported that Saccharomyces cerevisiae and Kluyveromyces sp. were the predominant species of "pito", a sorghum-based turbid beer brewed in Ghana [34]. In addition certain species, such as Candida albicans, Candida etchellsii, Candida kunwiensis, Dekkera anomala, Torulaspora delbrueckii, Saccharomyces carlsbergensis, have been found in opaque beers made from sorghum in Benin [35]. The decrease observed in most flora and especially in Coliform loads (total and thermo-tolerant coliforms, and E. coli) during fermentation could be partially explained by the activity of lactic acid bacteria contained in the fermented wort and the final ready-to-serve product [36]. The action of lactic acid bacteria in the inhibition of pathogens has been previously supported by many studies [6], [37]. In addition to their ability to produce organic acids, lactic acid bacteria can produce hydrogen peroxide, bacteriocins and nisin, which are very active against gram negative bacteria and intestinal pathogens such as Salmonella typhymurium, Shigella dysenteriae, Staphylococcus aureus, and E. coli [6], [38]. Furthermore, the alcohol produced during fermentation also helps to fight against pathogens contamination in the local beverages [39]. 


\section{CONCLUSION}

Hazards analysis through assessing the microbial changes during the processing of two turbid sorghum-based beers made in the Far-North region of Cameroon was highlighted in this study. The results showed that even if the red "té" and white "mpedli" sorghum beers are produced using different processes, many factors promote their contamination such as raw material and poor quality of the water used for beer's production, equipment involved during the manufacturing, the technique used for cooling the boiled wort and environment sanitation. It was also noticed that proper handling of raw material, execution of the heat treatment and fermentation can be effectively considered as critical points and they have to be checked and optimized for controlling microbial contamination. Careful attention should be paid to the high load of bacterial spores both in the malt and readyto-serve product because of the potential presence of $B$. cereus, one of major mesophilic spore-forming and foodborne pathogens. These findings provide useful information on the microflora found in the samples during the production of both turbid "kapsiki" beers and the microbial changes during some steps of processing. Data collected may also allow local producers to predict possible hazards of contamination and identify the real critical points. This could help to enhance the safety of indigenous sorghum-based beers locally produced in the northern part of Cameroon. So, the processors and sellers should be trained on good manufacturing practices and good hygiene practices such as processing in a clean and enclosed environment, have clean hands and clothes during and after processing, keep raw materials in a proper dry place, pre-boiling water and kept it in covered clean containers for cooling before use, to make use of proper utensils and equipment during and after production. All the results reported in this work could serve as a starting point for the understanding of the microbiological quality of the indigenous beers made in Cameroon.

\section{ACKNOWLEDGMENT}

The authors are grateful to the local producers of both sorghum beers who permitted us to assist during processing of each beer and allowed us to realize inspection of the production environment.

\section{REFERENCES}

[1] K. Motlhanka, K. Lebani, T, Boekhout, N. Zhou, "Fermentative Microbes of Khadi, a Traditional Alcoholic Beverage of Botswana," Fermentation, vol. 6, no. 2, pp. 51, 2020.

[2] G. Aboagye, S. Gbolonyo-Cass, N. K. Kortei, T. Annan, "Microbial evaluation and some proposed good manufacturing practices of locally prepared malted corn drink ("asaana") and Hibiscus sabdariffa calyxes extract ("sobolo") beverages sold at a university cafeteria in Ghana," Scientific African, e00330, 2020.

[3] R. Kubo, S. Funakawa, S. Araki, N. Kitabatake, "Production of indigenous alcoholic beverages in a rural village of Cameroon," Journal of the Institute of Brewing, vol. 120, no. 2, pp. 133-141, 2014

[4] J. N. Katongole, "The microbial succession in indigenous fermented maize products," Ph.D. thesis, University of the Free State, Bloemfontein. South Africa, 2008.

[5] J. De Roos, L. De Vuyst, "Microbial acidification, alcoholization, and aroma production during spontaneous lambic beer production,"
Journal of the Science of Food and Agriculture, vol. 99, no. 1, pp. 25 38, 2019.

[6] S. Aka, G. Konan, G. Fokou, K.M. Dje, B. Bonfoh, "Review on African traditional cereal beverages," Am. J. Res. Commun., vol. 2, no. 5, pp. 103-153, 2014.

[7] K. Motlhanka, N, Zhou, K. Lebani, "Microbial and chemical diversity of traditional non-cereal based alcoholic beverages of Sub-Saharan Africa," Beverages, vol. 4, no. 2, p. 36, 2018.

[8] M. Pauline, O. Alexandre, B.K. Andoseh, M. T. S. Abeline, T. Agatha, "Production technique and sensory evaluation of traditional alcoholic beverage based maize and banana," International journal of gastronomy and food science, vol. 10, pp. 11-15, 2017.

[9] W. E. van Beek, "Kapsiki beer dynamics," in Food resources and food choices in the Lake Chad basin, IRD, Paris, 2006, pp. 477-500.

[10] J. R. Bayoï, D. R. Darman, F-X. Etoa, "Technologie de fabrication, propriétés physico-chimiques et microbiologiques de la bière kapsiki blanche produite dans les monts Mandara au Nord - Cameroun," Afrique Sciences, vol. 12, pp. 123-134, 2016.

[11] J. R. Bayoï, D. R. Darman, "Traditional processing and quality control of the "red kapsiki": a local sorghum beer from northern Cameroon," in Brewing Technology, chap. 8, published by Intech, England, 2017, pp. 159-175.

[12] S. A. Kim, S. H. Jeon, N. H. Kim, H. W. Kim, N. Y. Lee, T. J. Cho and others, "Changes in the microbial composition of microbrewed beer during the process in the actual manufacturing line," Journal of food protection, vol. 78, no. 12, pp. 2233-2239, 2015.

[13] S. U. Oranusia, V. J. Umoha, J. K. P. Kwagab, "Hazards and critical control points of kunun-zaki, a non-alcoholic beverage in Northern Nigeria," Food Microbiology, vol. 20, pp. 127-132, 2003.

[14] ISO 4833:2003, “ Méthode horizontale pour le dénombrement des microorganismes-Technique de comptage des colonies à $30^{\circ} \mathrm{C}$ ", in Microbiologie des Aliments, International Standards Organization, Geneva, Switzerland, 2003.

[15] ISO 21527-2:2008, “ Méthode horizontale pour le dénombrement des levures et moisissures- Partie 1: Technique par comptage des colonies dans les produits à activité d'eau supérieure à 0.95 ", in Microbiologie des Aliments, International Standards Organization, Geneva, Switzerland, 2008.

[16] ISO 4832:2006, "Méthode horizontale pour le dénombrement des coliformes-Méthode par comptage des colonies", in Microbiologie des Aliments, International Standards Organization, Geneva, Switzerland, 2006.

[17] ISO 9308-1:2000, “ Recherche et dénombrement des Escherichia coli et des bactéries coliformes - Partie 1: Méthode par filtration sur membrane", in Microbiologie des Aliments, International Standards Organization, Geneva, Switzerland, 2000.

[18] SP-VG M008 (3) :1998, "Méthode de dénombrement des spores de microorganismes aérobies (méthode de routine par comptage des colonies à $30^{\circ} \mathrm{C}$ ) ", in Microbiologie des Aliments, Santé Publique Volksgezondheid, Bruxelles, Belgique. 1998.

[19] N. Maoura, M. Mbaiguinam, H. V. Nguyen, C. Gaillardin, J. Pourquie, "Identification and typing of yeast strains isolated from bili-bili, a traditional sorghum beer of Chad," African Journal of Biotechnology, vol. 4, no. 7, pp. 646-656, 2006.

[20] L. J Lima, H. J. Kamphuis, M. J. Nout, M. H. Zwietering, "Microbiota of cocoa powder with particular reference to aerobic thermoresistant spore-formers," Food Microbiology, vol. 28, pp. 573-582, 2011.

[21] F. Postollec, A. G. Mathot, M. Bernard, M. L. Divanac'h, S. Pavan, D. Sohier, "Tracking spore-forming bacteria in food: from natural biodiversity to selection by processes," International Journal of Food Microbiology, vol. 158, pp. 1-8, 2012.

[22] S. A. Scott, J. D. Brooks, J. Rakonjac, K. M. Walker, S. H. Flint, "The formation of thermophilic spores during the manufacture of whole milk powder," International Journal of Dairy Technology, vol. 60, pp. 109117,2007

[23] E. Baril, "Quantification de l'influence de l'environnement sur la formation et la thermorésistance des spores bactériennes," $\mathrm{Ph} . \mathrm{D}$. thesis, Université de Bretagne Occidentale, Brest, France, 2011.

[24] J. C. Augustin, "Challenges in risk assessment and predictive microbiology of foodborne spore-forming bacteria," Food Microbiology, vol. 28, pp. 209-213, 2011.

[25] M. Heyndrickx, "The importance of endospore-forming bacteria originating from soil for contamination of industrial food processing," Appl. Environ. Soil Sci., pp. 1-11, 2011.

[26] M. Bartoszewicz, B. M. Hansen, I. Swiecicka, "The members of the Bacillus cereus group are commonly present contaminants of fresh and heat-treated milk," Food Microbiology, vol. 25, pp. 588-596, 2008.

[27] S. J. Oomes, A. van Zuijlen, J.O. Hehenkamp, H. Witsenboer, J. Van der Vossen, S. Brul, "The characterisation of Bacillus spores occurring 
in the manufacturing of (low acid) canned products," International Journal of Food Microbiology, vol. 120, 85-94, 2007.

[28] S. A. Burgess, D. Lindsay, S. H. Flint, "Thermophilic bacilli and their importance in dairy processing," International Journal of Food Microbiology, vol. 144, 215-225, 2010.

[29] F. A. Oguntoyinbo, "Development of hazard analysis critical control points (HACCP) and enhancement of microbial safety quality during production of fermented legume based condiments in Nigeria," Nigerian Food Journal, vol. 30, no. 1, pp. 59-66, 2012.

[30] W. H. Holzapfel, "Appropriate starter culture technologies for smallscale fermentation in developing countries," International Journal of Food Microbiology, vol. 75, pp. 197-212, 2002.

[31] L. Jespersen, "Occurrence and taxonomic characteristics of strains of Saccharomyces cerevisiae predominant in African indigenous fermented foods and beverages," Yeast Research, vol. 3, pp. 191-200, 2003.

[32] M. K. Djè, S. Aka, Y. Z. Nanga, K. C. Yao, Y. G. Loukou, "Predominant lactic acid bacteria involved in the spontaneous fermentation step of tchapalo process, a traditional sorghum beer of Côte d'Ivoire," Research Journal of Biological Sciences, vol. 4, no. 7 , pp. 789-795, 2009.

[33] C. L. Ramos, E. G. de Almeida, G. V. de Melo Pereira, P. G. Cardoso, E. S. Dias, R. F. Schwan, "Determination of dynamic characteristics of microbiota in a fermented beverage produced by Brazilian Amerindians using culture-dependent and culture-independent methods," International Journal of Food Microbiology, vol. 140, no. 2, pp. 225-231, 2010.

[34] S. Sefa-Dedeh, A.I. Sanni, G. Tetteh, D. E. Sakyi, "Yeasts in the traditional brewing of pito in Ghana," World Journal of Microbiology and Biotechnology, vol. 15, no. 5, pp. 983-997, 1999.

[35] A. P. P. Kayodé, G. Vieira-Dalodé, A. R. Linnemann, S. O. Kotchoni, A. J. D. Hounhouigan, M. van Boeke, M. J. R. Nout, "Diversity of yeasts involved in the fermentation of tchoukoutou, an opaque sorghum beer from Benin," African Journal of Microbiology Research, vol. 5, no. 18 , pp. 2737-2742, 2011.

[36] M. M. Coman, M. C. Verdenelli, C. Cecchini, S. Silvi, C. Orpianesi, N. Boyko, A. Cresci, "In vitro evaluation of antimicrobial activity of Lactobacillus rhamnosus IMC 501, Lactobacillus paracasei IMC 502 and SYNBIO against pathogens," Journal of Applied Microbiology, vol. 117 , no. 2, pp. 518-527, 2014.

[37] R. D. Darman, J. J. Essia Ngang, F-X. Etoa, “Amelioration of cassava retting by a starter culture of three strains," International Journal of Innovation and Scientific Research, vol. 14, no. 2, pp. 268-277, 2015.

[38] J. G. LeBlanca, S. D. Todorov, "Bacteriocin producing lactic acid bacteria isolated from Boza. a traditional fermented beverage from Balkan Peninsula,"A. Méndez Vilas, Communicating current research and technological advances" pp. 1311-1320, 2011.

[39] H. C. Okereke, O. K. Achi, U. N. Ekwenye, F. A. Orji, "Antimicrobial properties of probiotic bacteria from various sources," African Journal of Biotechnology, vol. 39, no. 11, pp. 9416-9421, 2012. 